\title{
Crosstalk between p38 and Smad3 through TGF- $\beta 1$ in JEG-3 choriocarcinoma cells
}

\author{
QIAN XU, YUSI TAN, KONGYAN ZHANG and YUHONG LI \\ Department of Basic Medicine, Chengde Medical College, Chengde, Hebei 067000, P.R. China
}

Received April 8, 2013; Accepted June 10, 2013

DOI: 10.3892/ijo.2013.2026

\begin{abstract}
Choriocarcinoma is a highly malignant trophoblastic tumor related to pregnancy that often occurs with a complete hydatidiform mole. It grows quickly and can also widely metastasize to other organs or tissues through both the venous and lymphatic systems. The transforming growth factor- $\beta 1$ (TGF- $\beta 1$ ) belongs to a growth factor superfamily and has been suggested to play a critical role in regulating the genesis and development of choriocarcinoma through a variety of Smad-independent pathways, including the p38 MAPK pathway. Previous studies indicated that TGF- $\beta$ can activate the p38 MAPK pathway. In this study, we investigated Smad and p38 MAPK signaling in JEG-3 choriocarcinoma cells using p38 MAPK inhibitor and TGF- $\beta$ receptor inhibitor. Immunofluorescence and western blot assays were used to detect the proteins in Smad and p38 MAPK pathways. Our data demonstrated that TGF- $\beta$ can activate Smad 3 and induce Smad3 translocation into the nucleus in JEG-3 cells. Blockade of the TGF- $\beta$ pathway significantly reduced the expression levels of p38 and phospho-p38. p38 MAPK inhibitors (SB 203580) can attenuate TGF- $\beta 1$-induced Smad3 expression and suppress the activation of smad3. These findings indicate crosstalk between p38 and smad 3 through TGF- $\beta 1$ in choriocarcinoma cells.
\end{abstract}

\section{Introduction}

Choriocarcinoma is a highly malignant trophoblastic tumor that may occur after miscarriage, abortion, ectopic pregnancy or even normal pregnancy. In addition, it is characterized pathologically by the loss of its original structure of trophoblastic cells and excessive invasion capacity into the myometrium (1). Choriocarcinoma can also widely metastasize to other organs or tissues through both the venous and lymphatic systems.

Correspondence to: Professor Yuhong Li, Department of Basic Medicine, Chengde Medical College, Chengde, Hebei 067000, P.R. China

E-mail: 1798793521@qq.com

Key words: p38 MAPK, TGF- $\beta$, phosphorylation of smad3, phosphorylation of $\mathrm{p} 38$, choriocarcinoma
Early hematogenous and lymphatic metastatic spread can cause rapid death (2).

Although cure rate has been improved because of progress of chemotherapy, the toxicity and side effects still remain intolerable. Thus, it is urgent to explore the mechanisms of proliferation and invasiveness and find new target for drug therapy (3).

The transforming growth factor- $\beta 1$ (TGF- $\beta 1$ ) is a multifunctional polypeptide cytokine which belongs to a growth factor superfamily and it regulates a variety of cellular processes such as cell differentiation, proliferation, cycle arrest and extracellular matrix production (4). Our previous studies have demonstrated that TGF- $\beta 1$ promotes the invasive capability of choriocarcinoma JEG-3 cells and TGF/Smad pathway may play a critical role in the initiation of trophoblastic invasion process (5).

TGF/Smad pathway plays a pivotal role in intracellular signaling. TGF $\beta-1$ initiates signaling via a cell surface transmembrane serine/threonine kinase receptor complex which then activates its downstream Smad protein (6). There are three different functional groups of Smad proteins: receptorregulated R-Smads (Smad1, 2, 3, 5 and 8), the co-receptor Smad (Co-Smad) 4 and the inhibitory I-Smads (Smad6 and 7). In addition, the receptors of the TGF- $\beta$ superfamily consist of T $\beta R$ I and T $\beta R$ II. TGF $\beta-1$ ligand firstly binds to T $\beta R$ II, which then activates and combines to T $\beta R$ I. After that, receptor binding induces phosphorylation of its downstream proteins Smad2 and Smad3 (R-Smads) at a C terminal SSXS motif (7). Smad4 (Co-Smad) works as a mediator, carries phosphorylated R-Smad (Smad2 and Smad3) into the nuclear where target gene is processed (8).

The function of TGF $\beta /$ Smad signaling pathway in cancer progression is bidirectional. At the early stage of carcinogenesis, TGF- $\beta$ works as a tumor suppressor, which induces growth arrest, but in the later stage or in malignant tumor, it promotes the growth of tumor cells (9). Furthermore, our previous studies on the impacts of TGF- $\beta 1 / \mathrm{Smad}$ signal pathway in JEG-3 cell proliferation and invasion are in agreement with the above view (5).

P38 MAPK is a member of the MAPK family that is responsive to environmental stresses and inflammatory cytokines (10) and is involved in cell differentiation, apoptosis and autophagy. It is activated by a variety of cellular stresses including osmotic shock, inflammatory cytokines, lipopolysaccharides (LPS), Ultraviolet light and growth factors (11). 
As with other MAPK cascades, the membrane-proximal component is a MAPKKK, typically a MEKK or a mixed lineage kinase (MLK). The MAPKKK phosphorylates and then activates MKK3/6, the p38 MAPK kinases. MKK3/6 can also be activated directly by ASK1, which is stimulated by apoptotic stimuli (12). P38 MAPK is involved in regulation of HSP27 and MK2 (MAPKAPK-2), MK3 (MAPKAPK-3) and several transcription factors including ATF-2, Stat1, the Max/ Myc complex, MEF-2, Elk-1 and indirectly CREB via activation of MSK1 $(13,14)$. Consistent with important function in tumorigenesis, p38 MAPK signaling is also associated with cancer in humans.

Recent studies have shown that TGF- $\beta$ can also activate other signaling pathways including the p38 MAPK pathway (15). Studies on pulmonary epithelial cells suggest that TGF- $\beta$ activates p38 MAPK within $30 \mathrm{~min}$ and inhibition of p38 MAPK can significantly reduce TGF- $\beta 1$-dependent gene expression for the extracellular matrix-related gene fibronectin $(16,17)$. In addition, blockade of Smad pathway caused by Smad7 overexpression, can result in TGF- $\beta 1$-induced apoptosis mediated by p38 MAPK signaling (18).

Moreover, p38 MAPK inhibitors have been shown to inhibit TGF- $\beta /$ Smads signaling activity through affecting all levels of the TGF- $\beta$ receptor cascade by blockading Smad phosphorylation, nuclear translocation and target gene activation (4). The study of Dziembowska et al have shown that the p38 MAPK inhibitor SB202190, decreases the activity of Smad-dependent promoter induced by TGF- $\beta$ and the phosphorylation of Smad2 (19). According to the study of Tsukada et al, blockade of p38 MAPK signaling with SB203580 inhibited phosphorylation of Smad2 and Smad3 and the phosphorylation of the TGF- $\beta$ type I receptor, as there appears to be similarities in the ATP binding pocket between TGF- $\beta$ type I receptor and p38 MAPK (20). Thus, there is an unexpected interaction between TGF- $\beta$ and p38 MAPK pathways existing in a variety of diseases, but the molecular mechanism still remains unclear. Recently, few studies have been reported on crosstalk between TGF- $\beta$ and p38 MAPK in choriocarcinoma $(21,22)$.

Based on the above observations, we investigated signaling crosstalk between the p38 MAPK pathway and TGF- $\beta$ pathway in human choriocarcinoma cells by using the p38 MAPK inhibitor SB 203580 and the TGF- $\beta$ receptor inhibitor LY 364947.

\section{Materials and methods}

Materials. The human placental choriocarcinoma JEG-3 cell line was obtained from the State Key Laboratory of Reproductive Biology (SKLRB), Institute of Zoology (IOZ), Chinese Academy of Sciences (CAS). The study was approved by the ethics committee of the Natural Science Foundation of Hebei Province and the Education Department of Hebei province, Hebei, China.

\section{Methods}

JEG-3 cell culture. JEG-3 cells were cultured in an incubator with $5 \% \mathrm{CO}_{2}$ at $37^{\circ} \mathrm{C}$ in RPMI-1640 supplemented with $10 \%$ fetal bovine serum (FBS, Hangzhou Sijiqing Biological Engineering Materials Co., Ltd., Hangzhou, China), 200 mM glutamine, $100 \mathrm{mM}$ pyruvic acid $\mathrm{Na}, 100 \mu \mathrm{g} / \mathrm{ml}$ streptomycin and $100 \mathrm{U} / \mathrm{ml}$ penicillin. When the cells reached $\sim 70-80 \%$, they were subcultured with $0.25 \%$ trypsin and $0.02 \%$ EDTA (5).

Immunofluorescence analysis. JEG-3 cells were seeded on glass coverslips and cultured in 24-well plate with an initial concentration of $5 \times 10^{4}$ cells $/ \mathrm{ml}$ for $48 \mathrm{~h}$ prior to staining. Wells were divided into 8 groups as follows: control group, TGF- $\beta 1$ group, $1 \mu \mathrm{M}$ SB203580, $3 \mu \mathrm{M}$ SB203580, $1 \mu \mathrm{M}$ LY364947 (Sigma, St. Louis, MO, USA), $3 \mu \mathrm{M}$ LY364947. The cells were pretreated in appropriate wells to $80 \%$ confluence with different concentrations of TGF- $\beta 1$ receptor inhibitor (LY36494, Sigma) and p38 MAPK inhibitor (SB203580, Sigma) and cultured for $4 \mathrm{~h}$, then $1 \mu \mathrm{M}$ TGF- $\beta 1$ (PeproTech Inc., Rocky Hill, NJ, USA) was added into each well, except control group, continuing incubation for $2 \mathrm{~h}$. After the incubation with TGF- $\beta 1$, cells were fixed in $4 \%$ paraformaldehyde for $10 \mathrm{~min}$ at room temperature, then washed with PBS 3 times for $3 \mathrm{~min}$ each. Then, cells were permeabilized in $0.5 \mathrm{ml}$ of $0.1 \%$ Triton $\mathrm{X}-100$ for $15 \mathrm{~min}$ at room temperature (23). The cells were washed by PBS 3 times and followed by blocking in $10 \%$ goat serum for $20 \mathrm{~min}$. The primary antibody was diluted to the concentration of 1:100, then the cells were incubated in the primary antibody overnight at $4^{\circ} \mathrm{C}$. Before secondary antibody incubation, cells were placed into incubator with $5 \% \mathrm{CO}_{2}$ at $37^{\circ} \mathrm{C}$ for $45 \mathrm{~min}$, then washed 3 times for each with PBS (24). The secondary antibody (Epitomics Inc., USA) was diluted to the concentration of 1:50 and cells were incubated in secondary antibody at $37^{\circ} \mathrm{C}$ for $30 \mathrm{~min}$, followed by PBS washing 3 times for 5 min each. DAPI, with the concentration of 1:100, was added to the cell for $5 \mathrm{~min}$ at room temperature in the dark. The primary antibodies were used as follows: for p-Smad3 (Epitomics); for p38 (Epitomics); and p-p38 (Epitomics). Images were viewed by immunofluorescence microscopy (Ti-u, Nikon Eclipse, Japan).

Western blot analysis. Cells were incubated in a 6-well plate with an initial concentration of $5 \times 10^{4}$ cells $/ \mathrm{ml}$ for $48 \mathrm{~h}$. Wells were divided into 6 groups as follows: control group, TGF- $\beta 1$ group, $1 \mu \mathrm{M}$ SB203580, $3 \mu \mathrm{M} \mathrm{SB} 203580,1 \mu \mathrm{M}$ LY364947, $3 \mu \mathrm{M}$ LY364947. When cells reached $\sim 80 \%$, the same treatments were given to cells as stated in immunofluorescence analysis. The cells were collected and lysed on ice with buffer (10\% glycerol, 2.3\% SDS, $62.5 \mathrm{mM}$ Tris, pH $6.8150 \mathrm{mM}$ $\mathrm{NaCl}, 10 \mathrm{mM}$ EDTA, $1 \mathrm{mg} / \mathrm{ml}$ leupeptin, $1 \mathrm{mg} / \mathrm{ml}$ pepstatin, $5 \mathrm{mg} / \mathrm{ml}$ chymostatin, $1 \mathrm{mg} / \mathrm{ml}$ aprotinin, $1 \mathrm{mM}$ phenylmethylsulphonyl fluoride) and centrifuged at 12,000 rpm for 5 min at $4^{\circ} \mathrm{C}$. The supernatants were collected as a whole cell protein extract. Protein concentrations were determined by the bicinchoninic acid assay (25). Then, equal amounts of sample were denatured at $95^{\circ} \mathrm{C}$ for $15 \mathrm{~min}$ and separated on $12 \%$ sodium dodecyl sulfate-polyacrylamide gel electrophoresis (SDS-PAGE) and transferred to polyvinylidene difluoride (PVDF) membranes. Membranes were blocked with 5\% non-fat milk in TBS-T (10 mM Tris, $\mathrm{pH} 8.0,150 \mathrm{mM} \mathrm{NaCl}$ and $0.1 \%$ Tween-20) for $2 \mathrm{~h}$, at room temperature followed by TBST washing 3 times and incubated with primary antibody (diluted 1:500) overnight at $4^{\circ} \mathrm{C}$ (26). After TBST buffer washing, the membranes were incubated with the secondary antibody (diluted 1:2000) for $1 \mathrm{~h}$ at room temperature. $\beta$-actin was the internal control. The primary antibodies were: for 


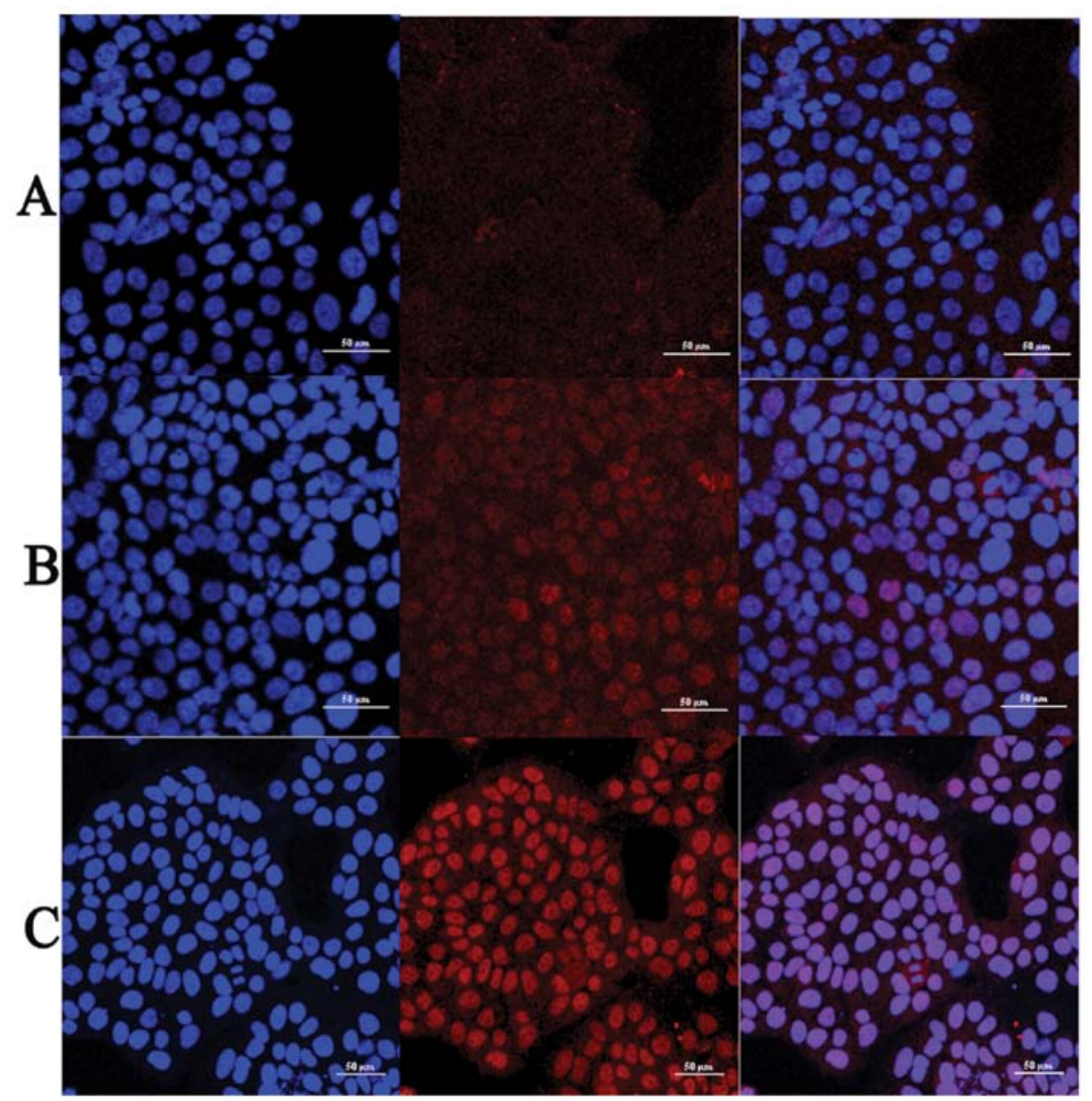

Figure 1. JEG-3 cells were treated by TGF- $\beta 1$ with the concentrations of $5 \mathrm{ng} / \mathrm{ml}$. The cellular localization of p-smad 3 in JEG-3 cell line was detected by immunofluorescence assay. Nuclear location was stained by blue fluorescent and phosphorylation of smad 3 was stained by red fluorescent. Phosphorylation of smad3 was weakly distributed in the cytoplasm (A). Smad3 translocates to the nucleus with TGF- $\beta 1$ treatment and the intensity of p-smad 3 staining gradually increased at $2 \mathrm{~h}(\mathrm{~B})$ and $6 \mathrm{~h}(\mathrm{C})$.

Smad3 (Santa Cruz Biotechnology, Inc., Santa Cruz, CA, USA); for p-Smad3 (Epitomics); for p38 (Epitomics); and p-p38 (Epitomics). Immunoreactive bands were detected with Super ECL Plus Iuminescence fluid (Applygen Technologies Inc., Beijing, China). The densities of the bands were scanned and calculated with Quantity One software (Bio-Rad, Hercules, CA, USA).

Statistical analysis. All data were expressed as means \pm standard deviation (SD). One-way analysis of variance (ANOVA) was used to compare differences among groups. The SNK-q test was performed to compare the difference of each twogroup. Differences were considered statistically significant at $\mathrm{P}<0.05$. All statistical analysis was performed using SPSS 19.0 software (SPSS, Chicago, IL, USA).

\section{Results}

TGF- $\beta 1$ induces activation and nuclear translocation of Smad3 in JEG-3 cells. JEG-3 cells were treated by TGF- $\beta 1$ with the concentrations of $5 \mathrm{ng} / \mathrm{ml}$. Anti p-Smad3 antibody was employed to determine the cellular localization of phospho-smad 3 in JEG-3 cell line. We found that TGF- $\beta 1$ treatment induces phosphorylation of Smad3 and the inten- sity of phospho-smad3 immunofluorescence staining was significantly increased, compared with control group (Fig. 1A and B). TGF- $\beta 1$ also induced Smad3 nuclear translocation. We observed that phospho-smad3 showed a diffuse cytoplasmic staining pattern in control group and slight staining in the nucleus (Fig. 1A). For the group of $2 \mathrm{~h}$ TGF- $\beta 1$ treatment, phospho-smad3 staining appeared in both the cytoplasm and nucleus (Fig. 1B) whereas in the group of $6 \mathrm{~h}$ TGF- $\beta 1$ treatment, almost $70 \%$ of phospho-smad3 staining was in the nucleus (Fig. 1C). Thus TGF- $\beta 1$ activated and induced nuclear translocation of Smad3 in a time-dependent manner in JEG-3 cells.

In western blot analysis, JEG-3 cells were separately pretreated with LY364947, a specific inhibitor of TGF- $\beta 1$ receptor and SB203580, a specific inhibitor of p38 MAPK, at a series of concentrations $(1$ and $3 \mu \mathrm{M})$ for $4 \mathrm{~h}$, then stimulated by TGF- $\beta 1$ and further cultured for $2 \mathrm{~h}$. However, for TGF- $\beta 1$ group, cells were treated with TGF- $\beta 1$ alone. The protein expression of Smad3 and phospho-smad3 significantly increased in TGF- $\beta 1$ group, comparing with the control group $(\mathrm{P}<0.05)$ (Fig. 4). It also revealed that TGF- $\beta 1$ promoted the protein expression of Smad3 and phospho-smad3. With the increasing concentrations of inhibitors, the Smad 3 and phospho-smad3 protein levels in LY364947 group gradually 


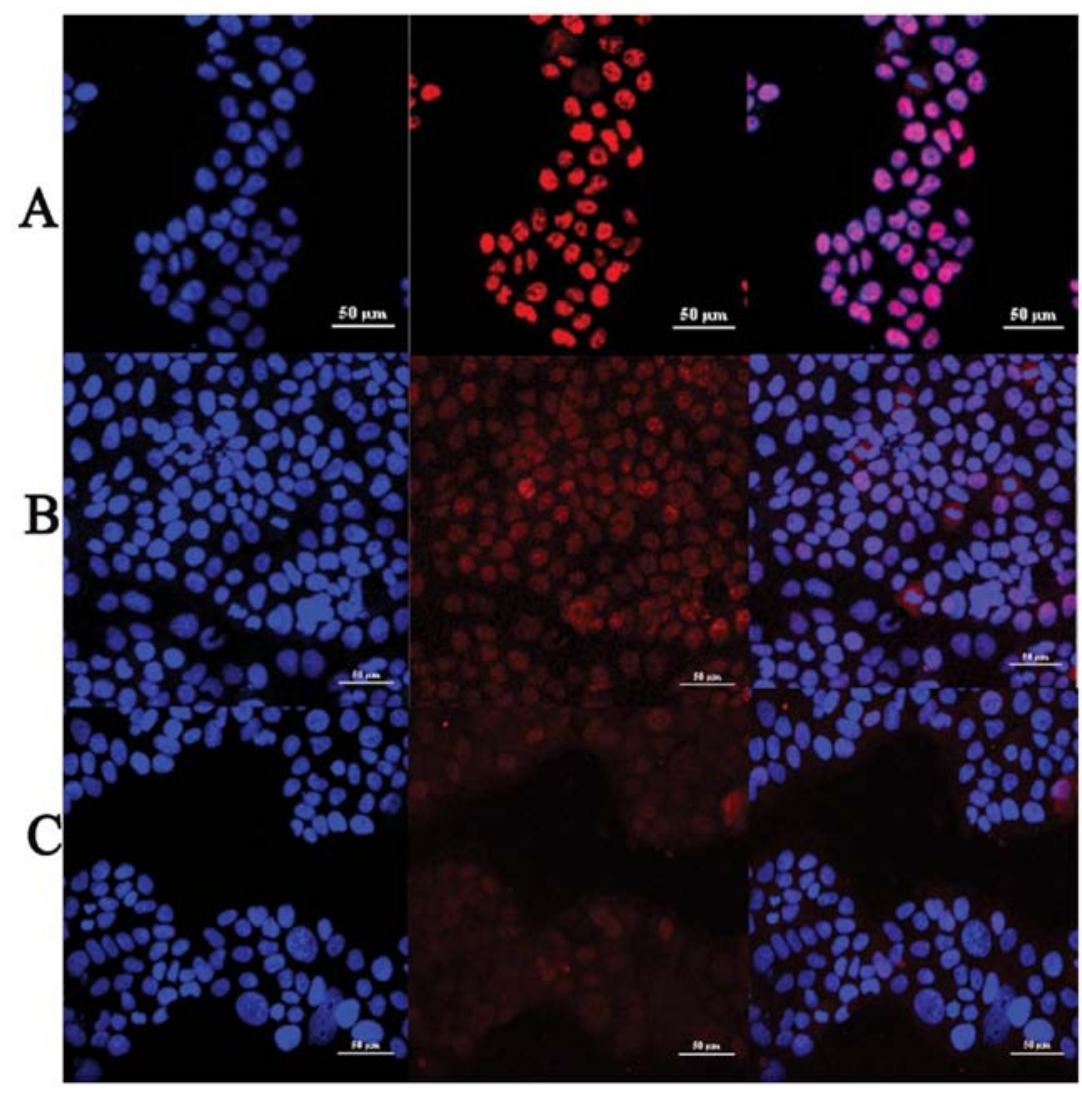

Figure 2. JEG-3 cells were pretreated with P38 inhibitor (SB203580) at 1 and $3 \mu \mathrm{M}$, respectively, for $4 \mathrm{~h}$, then stimulated with TGF- $\beta 1$ for $2 \mathrm{~h}$. Nuclear location was stained by blue fluorescent and phosphorylation of p38 was stained by red fluorescent. Phosphorylation of p38 was mainly expressed in JEG-3 cell nucleus (A). SB203580 inhibited phosphorylation of p38 and p38 nuclear translocation (B and C).

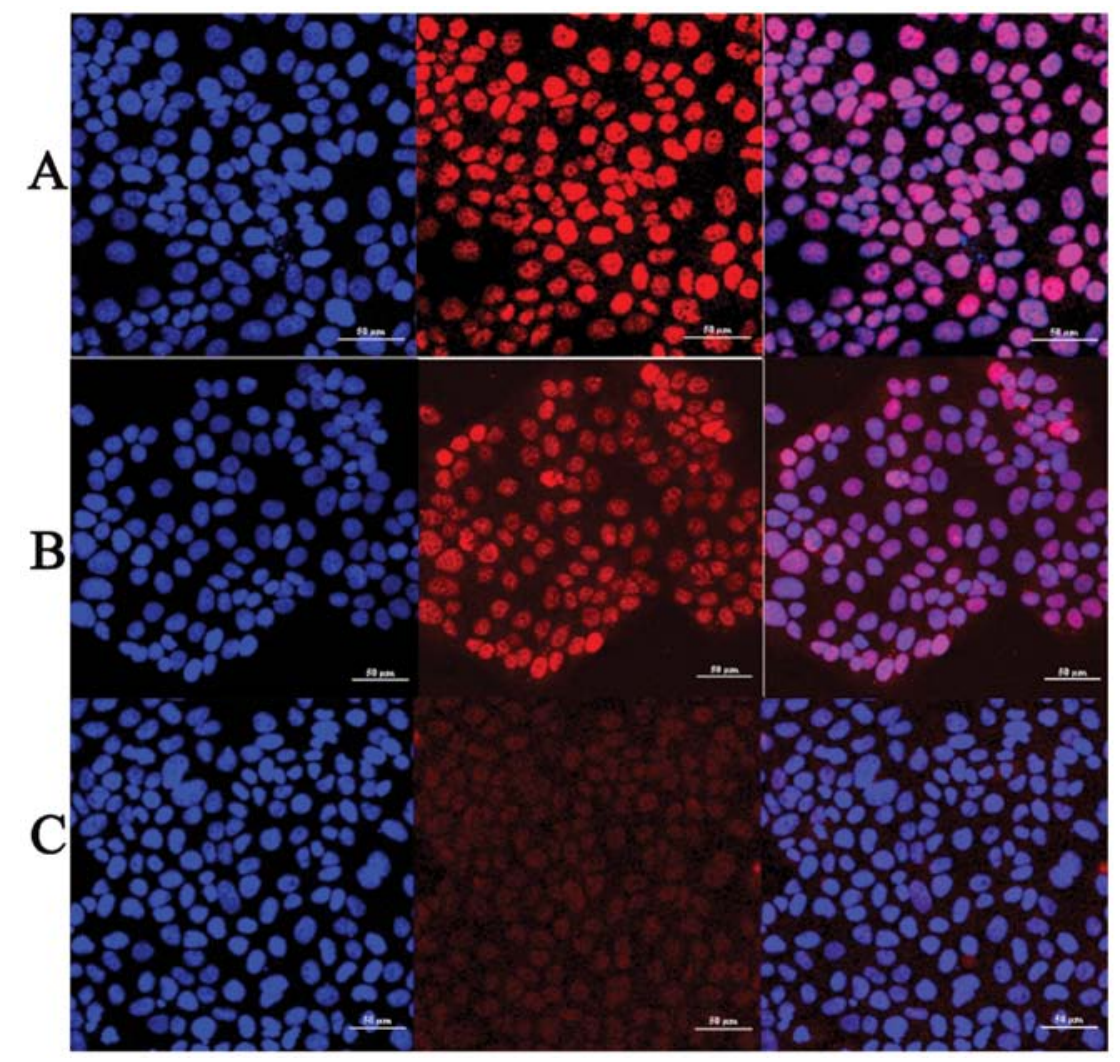

Figure 3. JEG-3 cells were pretreated with specific inhibitor of TGF- $\beta 1$ receptor (LY364947) at 1 and $3 \mu \mathrm{M}$, respectively, for $4 \mathrm{~h}$, then stimulated with TGF- $\beta 1$ for $2 \mathrm{~h}$. Nuclear location was stained by blue fluorescent and phosphorylation of p38 was stained by red fluorescent. Untreated cells are included as a positive control for p-p38 expression (A). Phosphorylation of p38 and nuclear translocation gradually inhibited with the increasing concentration of LY364947 treatment (B and C). 


\section{Control $\quad 5 \mu \mathrm{g} / \quad 1 \mu \mathrm{M} \quad 3 \mu \mathrm{M} \quad 1 \mu \mathrm{M} \quad 3 \mu \mathrm{M}$ TGF- $\beta 1 \quad$ LY364947 LY364947 SB203580 SB203580}

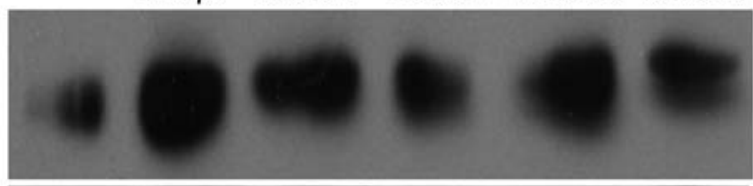

P-Smad3

$58 \mathrm{kDa}$

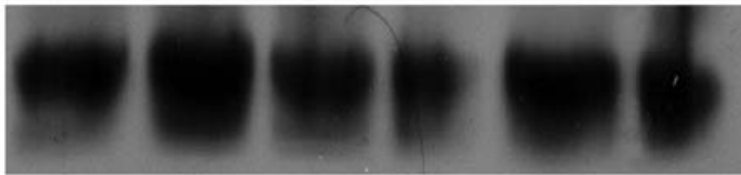

Smad3

$58 \mathrm{kDa}$

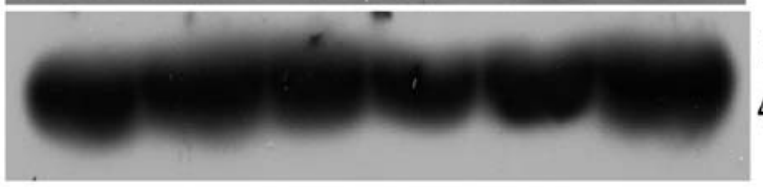

$\beta$-actin

$43 \mathrm{kDa}$

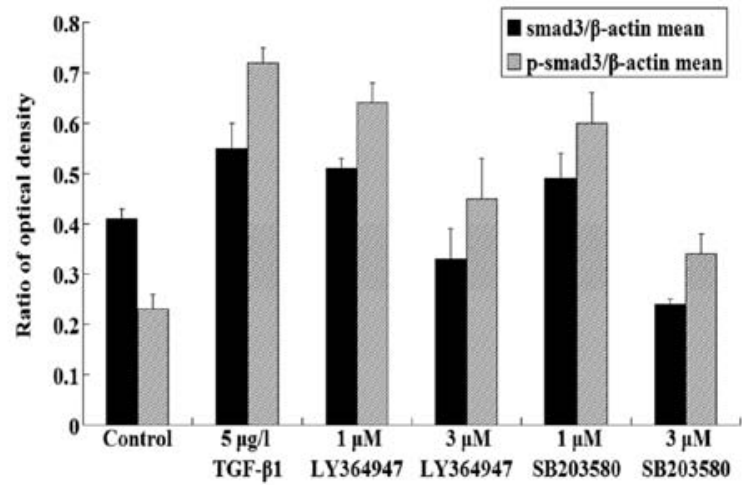

Figure 4. LY364947 and SB203580 decrease TGF- $\beta 1$-induced phosphorylation of smad3. JEG-3 cells were incubated in presence or absence of LY364947 $(1$ and $3 \mu \mathrm{M})$ or SB203580 (1 and $3 \mu \mathrm{M})$ for $4 \mathrm{~h}$ and then stimulated with TGF- $\beta 1(5 \mathrm{ng} / \mathrm{ml})$ for $2 \mathrm{~h}$. The cell lysates were immunoblotted with phospho-smad3 antibody. Equal loading of proteins in each lane was confirmed by reprobing the same blot with smad 3 antibody. The data are presented as the mean $\pm \mathrm{SD}(\mathrm{P}<0.05)$. The results shown are representative of at least three experiments.

reduced compared with the control and TGF $\beta$ groups $(\mathrm{P}<0.05)$ (Fig. 4). This result demonstrated that inhibition of TGF- $\beta 1$ receptor by inhibitor LY364947 blocked the smad3 activation and nuclear translocation.

TGF- $\beta 1$ induces activation and nuclear translocation of $p 38$ in JEG-3 cells. In western blot analysis, protein levels of p38 and phospho-p38 were obviously increased in TGF- $\beta 1$ group, which indicated that TGF- $\beta 1$ promoted the expression of $\mathrm{p} 38$ and phospho-p38. However, in LY364947 groups, p38 and phospho-p38 protein expression levels decreased as concentrations of LY364947 increased ( $\mathrm{P}<0.05)$ (Fig. 5).

In immunofluorescence analysis, JEG-3 cells were pretreated with inhibitor of TGF- $\beta 1$ receptor (LY364947) 1 and $3 \mu \mathrm{M}$, respectively, and cultured for $4 \mathrm{~h}$. Then TGF- $\beta 1$ with the concentration of $1 \mu \mathrm{M}$ was added, except for control group, continuing incubated for $2 \mathrm{~h}$. Phospho-p38 expression was detected in the cells of LY364947 group. Results showed that compared with control group, the intensity of phospho-p38 was reduced with increasing concentrations of LY364947 inhibitor (Fig. 3). Nuclear staining of phospho-p38 also changed into diffuse cytoplasmic staining pattern due
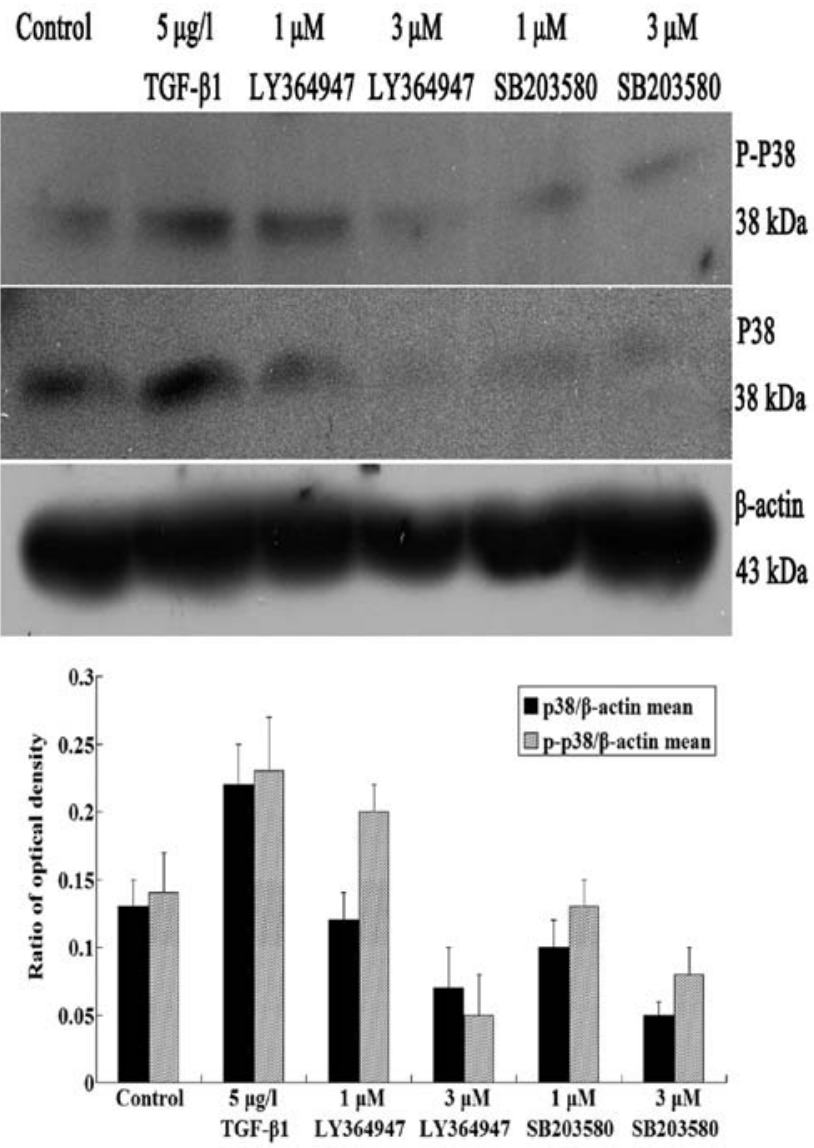

Figure 5. TGF- $\beta 1$ activated p38 MAPK pathway and promotes phosphorylation of p38 MAPK. JEG-3 cells were separately treated with LY364947 (1 and $3 \mu \mathrm{M})$ or SB203580 (1 and $3 \mu \mathrm{M})$ for $4 \mathrm{~h}$ and then stimulated with TGF- $\beta 1(5 \mathrm{ng} / \mathrm{ml})$ for $2 \mathrm{~h}$. The cell lysates were immunoblotted with phosphop38 MAPK antibody. Equal loading of proteins in each lane was confirmed by reprobing the same blot with p38 antibody. The data are presented as the mean $\pm \mathrm{SD}(\mathrm{P}<0.05)$. The results shown are representative of at least three experiments.

to LY364947 treatment (Fig. 3), indicating that inhibition of TGF- $\beta 1$ by inhibitor LY364947 blocked the activation and nuclear translocation of p38 in a dose-dependent manner.

Inhibition of p38 MAPK reduces expression level of smad3 and TGF- $\beta 1$-induced activation of smad 3

SB203580 inhibits p38 in a dose-dependent manner. In immunofluorescence analysis, the same concentration of $\mathrm{p} 38$ inhibitor (SB203580) was employed and phospho-p38 expression was detected in the cells of SB203580 group. For control group, phospho-p38 exhibited nuclear staining in JEG-3 cells (Fig. 2A). However, in SB203580 groups, phospho-p38 nuclear staining gradually changed into diffuse cytoplasmic staining pattern as concentrations of the inhibitor increased. In additon, intensity of the staining was reduced by $\sim 50 \%$ in the presence of $1 \mu \mathrm{M} \mathrm{SB} 203580$ (Fig. 2B), 70\% at $3 \mu \mathrm{M}$ (Fig. 2C). It indicated that inhibition of p38 MAPK by inhibitor SB203580 also blocked the activation and nuclear translocation of p38 in a dose-dependent manner.

SB203580 attenuates TGF- $\beta 1$-induced activation of $p 38$ and smad3. In immunofluorescence analysis, anti p-p38 antibody was employed to detected phospho-p38 expression in JEG-3 
cell line. For control group, phospho-p38 exhibited nuclear staining in JEG-3 cells (Fig. 2A). However in SB203580 groups, phospho-p38 nuclear staining gradually changed into diffuse cytoplasmic staining pattern as concentrations of the inhibitor increased. In additon, intensity of the staining reduced by $\sim 50 \%$ in the presence of $1 \mu \mathrm{M} \mathrm{SB} 203580$ (Fig. 2B), $70 \%$ at $3 \mu \mathrm{M}$ (Fig. $2 \mathrm{C}$ ).

In western blot analysis, with the increasing concentrations of p38 inhibitors, TGF- $\beta 1$-induced phospho-p38 protein levels were decreased compared with control and TGF $\beta$ groups $(\mathrm{P}<0.05)$ (Fig. 4). In additon, the phospho-smad3 protein levels in SB203580 groups gradually reduced as the concentrations of p38 inhibitors increased, compared with control and TGF $\beta$ groups $(\mathrm{P}<0.05)($ Fig. 4). Thus SB203580 attenuated TGF- $\beta 1$ induced activation of $\mathrm{p} 38$ and $\operatorname{smad} 3$.

SB203580 decreases the expression level of Smad3. In western blot analysis, the treatment were as stated above. Anti-Smad3 antibody was used to detect the expression level of Smad3. With the increasing concentrations of inhibitors, the smad3 level in the SB203580 groups gradually reduced compared with the other two groups $(\mathrm{P}<0.05)$ (Fig. 4). This result demonstrated that SB203580 decreased the expression level of smad3 in a dose-dependent manner.

\section{Discussion}

Choriocarcinoma is a gestational trophoblastic disease. It is a highly malignant tumor that originates in developing trophoblasts (27). The cancer often occurs with a complete hydatidiform mole (28). The abnormal tissue of the mole can continue to grow even after it is removed. Although choriocarcinoma is a rare human malignancy which is curable, it is a potentially fatal disease (29). At present, availability of different diagnostic aids has turned the prognosis highly favorable (1), however, many patients still cannot get effective medical treatment. It is closely related with cell malignancy of choriocarcinoma and trophoblastic invasion (27).

TGF- $\beta$ appears to be a key factor in the development of choriocarcinoma. Our previous studies have suggested that TGF- $\beta 1$ can promote JEG-3 cell proliferation and it further enhances the invasive ability of JEG-3 cells (5). Phosphorylation of smad 3 and its nuclear translocation are critical processes in the whole TGF $\beta /$ Smads pathway. Therefore the process of smad 3 activation is observed by immunofluorescence (30). Our result reveals that TGF- $\beta 1$ not only activates $\mathrm{Smad} 3$, but also induces $\operatorname{smad} 3$ translocation into nucleus in JEG-3 cell line. The translocation induced by TGF- $\beta 1$ is almost complete in $6 \mathrm{~h}$ and the nuclear expression of phospho-smad3 is strong positive compared with the control group, whereas, there is still a small amount of phospho-smad3 expressed in the cytoplasm of untreated cells, which indicates that TGF- $\beta$ autocrine mechanism may exist in JEG-3 cells (31).

After determining the nuclear translocation of Smad3, we treated the JEG-3 cells, respectively, with the specific inhibitors LY364947 and SB203580. Then phospho-p38 expression in the nucleus was detected through immunofluorescence analysis. Not only in the SB203580 group but also in the LY364947 group, we find that with increasing concentra- tions of inhibitors, the intensity of phospho-p38 in JEG-3 cell nucleus is reduced. It demonstrates that the inhibitor of TGF- $\beta 1$ receptor can block activation of $\mathrm{p} 38$ MAPK signaling pathway, indicating that there might be interaction between TGF- $\beta$ signaling and p38 MAPK signaling pathways (19).

The development of choriocarcinoma is a complex and multistep process which includes both cell proliferation and migration (32). Although the more exact mechanisms are still controversial, the crosstalk between TGF- $\beta$ and p38 MAPK signaling pathway may contribute to solving the issue. Besides the results of immunofluorescence on p38 nuclear translocation, our study revealed that $\mathrm{p} 38$ and phospho-p38 protein levels were promoted after TGF- $\beta$ stimulation and it suggests that TGF- $\beta$ can induce the activation of p38 MAPK. An obvious downregulation of $\mathrm{p} 38$ and phospho-p38 protein expression in TGF- $\beta$-induced JEG-3 cells was observed in treatments with LY364947 and SB203580. These results are consistent with those of Bakin et al (33). The results presented here also indicate that TGF- $\beta 1$ receptor inhibition can suppress activation of p38 MAPK signaling pathway.

Some research on p38 MAPK mediated myofibroblasts in hepatic stellate cells have manifested that phosphorylation of Smad 3 activated by TGF- $\beta$ is impaired severely in myofibroblasts during chronic liver injury, whereas phosphorylation of Smad3 at the linker region induced by p38 MAPK pathway significantly increased (34). It indicates that p38 MAPK pathways can also activate Smad3 in hepatic stellate cells. However, treatment of SiHa human cervical carcinoma cells with TGF- $\beta$ in the presence of $\mathrm{p} 38$ MAPK inhibitor does not significantly inhibit the phosphorylation of Smad $2 / 3$ induced by TGF- $\beta$, whereas it reduces phosphorylation of ATF2 (33). Besides the immunofluorescence on Smad3 nuclear translocation, we have also detected the protein expression levels of Smad3 and phospho-smad3 with separate pretreatment of specific p38 MAPK inhibitor (SB203580) and TGF- $\beta$ receptor inhibitor (LY364947), following by TGF- $\beta 1$ stimulation. We utilized untreated cells as control group and treatment with TGF- $\beta$ receptor inhibitor as negative control. Our data indicate that protein levels of Smad3 and phospho-smad3 are significantly reduced by using LY364947 and inhibited dosedependently. Similar results were observed with the treatment of SB203580, but the inhibitory effect was slightly lower than the suppression of TGF- $\beta$ receptor group. It reveals that the blockade of p38 MAPK pathway can downregulate protein level of Smad3 and also inhibits the activation of Smad3. In addition, we believe that p38 MAPK induced activation of Smad3 has so far appeared to be cell type-dependent, thus necessitating a careful examination of this mechanism.

In conclusion, TGF- $\beta$ and $\mathrm{p} 38$ MAPK pathways play a central role in regulating basic cellular processes such as cell differentiation, proliferation and extracellular matrix production (35). However, few relative studies on the interaction of these two signaling pathways in choriocarcinoma have been reported. The development of choriocarcinoma has direct relationship with the abnormal cellular signal transduction pathways. Whether carcinogenic or not, the active level plays an important role in the process of tumor development (36). In this study, $\mathrm{p} 38$ and Smad3 protein expression is at the expressive level, whereas phospho-p38 and phospho-Smad3 protein expression at active level. Both $\mathrm{p} 38$ and phospho-p38 protein 
expression is reduced through the use of TGF- $\beta 1$ receptor inhibitor. In addition, p38 MAPK inhibitors can also attenuate TGF- $\beta 1$-induced Smad3 expression and suppress activation of Smad3. These results suggest that TGF- $\beta$ and p38 MAPK signaling are both closely associated with choriocarcinoma genesis, and progression. Further clarifying the mechanisms of TGF- $\beta$ and p38 MAPK pathways in cell models might be informative for the field of therapeutic approaches.

\section{References}

1. McGee $\mathrm{J}$ and Covens A: Gestational trophoblastic disease: hydatidiform mole, nonmetastatic and metastatic gestational trophoblastic tumor: diagnosis and management. In: Comprehensive Gynecology. 6th edition. Lentz GM, Lobo RA Gershenson DM and Katz VL (eds). Mosby Elsevier, Philadelphia, PA, chapter 35, 2012.

2. Braunstein GD: Endocrine changes in pregnancy. In: Williams Textbook of Endocrinology. Melmed S, Polonsky KS, Larsen PR and Kronenberg HM (eds). 12th edition. Saunders Elsevier, Philadelphia, PA, chapter 21, 2011

3. Yamamoto E, Ino K, Yamamoto T, Sumigama S, Nawa A, Nomura $\mathrm{S}$ and Kikkawa F: A pure nongestational choriocarcinoma of the ovary diagnosed with short tandem repeat analysis: case report and review of the literature. Int J Gynecol Cancer 17: 254-258, 2007.

4. Fu Y, O'Connor LM, Shepherd TG and Nachtigal MW: The p38 MAPK inhibitor, PD169316, inhibits transforming growth factor beta-induced Smad signaling in human ovarian cancer cells. Biochem Biophys Res Commun 310: 391-397, 2003.

5. Li Y, Xu Q, Zhang Z, Liu S, Shi C and Tan Y: The impact of TGF- $\beta 1$ on the mRNA expression of T $\beta R$ I, T $\beta$ R II, Smad4 and the invasiveness of the JEG-3 placental choriocarcinoma cell line. Oncol Lett 4: 1344-1348, 2012.

6. Watanabe H, de Caestecker MP and Yamada Y: Transcriptional cross-talk between Smad, ERK1/2, and p38 mitogen-activated protein kinase pathways regulates transforming growth factor- $\beta$ induced aggrecan gene expression in chondrogenic ATDC5 cells. J Biol Chem 276: 466-473, 2001.

7. Ikushima $\mathrm{H}$ and Miyazono K: Cellular context-dependent 'colors' of transforming growth factor- $\beta$ signaling. Cancer Sci 101: 306-312, 2010.

8. Nickl-Jockschat T, Arslan F, Doerfelt A, Bogdahn U, Bosserhoff A and Hau P: An imbalance between Smad and MAPK pathways is responsible for TGF- $\beta$ tumor promoting effects in high-grade gliomas. Int J Oncol 30: 499-507, 2007.

9. Chapnick DA, Warner L, Bernet J, Rao T and Liu X: Partners in crime: the TGF $\beta$ and MAPK pathways in cancer progression. Cell Biosci 1: 42-49, 2011.

10. Coulthard LR, White DE, Jones DL, McDermott MF and Burchill SA: p38(MAPK): stress responses from molecular mechanisms to therapeutics. Trends Mol Med 15: 369-379, 2009.

11. Takekawa M, Kubota $Y$, Nakamura $T$ and Ichikawa $K$ Regulation of stress-activated MAP kinase pathways during cell fate decisions. Nagoya J Med Sci 73: 1-14, 2011.

12. Cuenda A and Rousseau S: p38 MAP-kinases pathway regulation, function and role in human diseases. Biochim Biophys Acta 1773: 1358-1375, 2007.

13. Shiryaev A and Moens U: Mitogen-activated protein kinase p38 and MK2, MK3 and MK5: ménage à trois or ménage à quatre? Cell Signal 22: 1185-1192, 2010

14. Freund A, Patil CK and Campisi J: p38MAPK is a novel DNA damage response-independent regulator of the senescenceassociated secretory phenotype. EMBO J 30: 1536-1548, 2011.

15. Li J, Deane JA, Campanale NV, Bertram JF and Ricardo SD Blockade of p38 mitogen-activated protein kinase and TGF- $\beta 1$ / Smad signaling pathway rescues bone marrow-derived peritubular capillary endothelial cells in adriamycin-induced nephrosis J Am Soc Nephrol 10: 2799-2811, 2006.

16. Gui T, Sun Y, Shimokado A and Muragaki Y: The roles of mitogen-activated protein kinase pathways in TGF- $\beta$-induced epithelial-mesenchymal transition. J Signal Transduct 12 : $1155-1165,2012$.
17. Kolosova I, Nethery D and Kern JA: Role of Smad2/3 and p38 MAP kinase in TGF- $\beta 1$-induced epithelial-mesenchymal transition of pulmonary epithelial cells. J Cell Physiol 226: 1248-1254, 2011.

18. Undevia NS, Dorscheid DR, Marroquin BA, et al: Smad and p38-MAPK signaling mediates apoptotic effects of transforming growth factor- $\beta$ in human airway epithelial cells. Am J Physiol Lung Cell Mol Physiol 287: L515-L524, 2004.

19. Dziembowska M, Danilkiewicz M, Wesolowska A, et al: Crosstalk between Smad and p38MAPK signalling in transforming growth factor beta signal transduction in human glioblastoma cells. Biochem Biophy Res Commun 354: 1101-1106, 2007.

20. Tsukada S, Westwick JK, Ikejima K, et al: SMAD and p38 MAPK signaling pathways independently regulate $\alpha 1$ (I) collagen gene expression in unstimulated and transforming growth factor- $\beta$ stimulated hepatic stellate cells. J Biol Chem 280: 10055-10064, 2005.

21. Han YC, Zeng XX, Wang R, Zhao Y, Li BL and Song M: Correlation of $\mathrm{p} 38$ mitogen-activated protein kinase signal transduction pathway to uPA expression in breast cancer. Ai Zheng 26: 48-53, 2007.

22. Zhang X-Z, Huang D, Wu F, et al: Experimental study on role of TGF- $\beta 1 /$ p38 mitogen-activated protein kinase pathway to renal interstitial fibrosis and intervention mechanisms of Kang Xianling Decoction. China J Traditional Chinese Medicine Pharmacy 26: 245-248, 2011.

23. Chen YX, Weng ZH and Zhang SL: Notch3 regulates the activation of hepatic stellate cells. World J Gastroenterol 18: 1397-1403, 2012.

24. Vyas B, Ishikawa K, Duflo S, Chen X and Thibeault SL: Inhibitory effects of HGF and IL- 6 on TGF- $\beta 1$ mediated vocal fibroblastmyofibroblast differentiation. Ann Otol Rhinol Laryngol 119: 350-357, 2010.

25. Kashiwagi Y, Horie K, Kanno C, Inomata M, et al: Trichostatin A-induced TGF- $\beta$ type II receptor expression in retinoblastoma cell lines. Invest Ophthalmol Vis Sci 51: 679-685, 2010.

26. Meng XM, Huang XR, Chung AC, Qin W, Shao X, et al: Smad2 protects against TGF- $\beta /$ Smad3-mediated renal fibrosis. J Am Soc Nephrol 21: 1477-1487, 2010.

27. Goldstein DP and Berkowitz RS: Gestational trophoblastic disease. In: Abeloff's Clinical Oncology. 4th edition. Abeloff MD, Armitage JO, Niederhuber JE, Kastan MB and McKenna WG (eds). Elsevier Churchill Livingstone, Philadelphia, PA, pp94-112, 2008.

28. Gerulath AH and Toronto: Gestational Trophoblastic Disease. Sogc Clinic Practice Guidelines 114: 1-6, 2002.

29. Denkert C, Darb-Esfahani S, Loibl S, Anagnostopoulos I and Jöhrens K: Anti-cancer immune response mechanisms in neoad juvant and targeted therapy. Semin Immunopathol 33: 341-351, 2011.

30. Giampieri S, Pinner S and Sahai E: Intravital imaging illuminates transforming growth factor beta signaling switches during metastasis. Cancer Res 70: 3435-3439, 2010.

31. Tsai S, Hollenbeck ST, Ryer EJ, Edlin R, Yamanouchi D, Kundi R, Wang C, Liu B and Kent KC: TGF- $\beta$ through Smad3 signaling stimulates vascular smooth muscle cell proliferation and neointimal formation. Am J Physiol Heart Circ Physiol 297: H540-H549, 2009.

32. Javelaud D and Mauviel A: Crosstalk mechanisms between the mitogen-activated protein kinase pathways and Smad signaling downstream of TGF- $\beta$ : implications for carcinogenesis. Oncogene 24: 5742-5750, 2005.

33. Bakin AV, Rinehart C, Tomlinson AK and Arteaga CL: p38 mitogen-activated protein kinase is required for TGF $\beta$-mediated fibroblastic transdifferentiation and cell migration. J Cell Sci 115: 3193-3206, 2002.

34. Furukawa F, Matsuzaki K, Mori S, Tahashi Y, et al: p38 MAPK mediates fibrogenic signal through Smad3 phosphorylation in rat myofibroblasts. Hepatology 38: 879-889, 2007.

35. Ungefroren H, Groth S, Sebens S, Lehnert H, Gieseler F and Fändrich F: Differential roles of Smad2 and Smad3 in the regulation of TGF- $\beta 1$-mediated growth inhibition and cell migration in pancreatic ductal adenocarcinoma cells: control by Rac1. Mol Cancer 10: 671-679, 2011.

36. Grzmil M, Morin Jr P, Lino MM, et al: MAP kinase-interacting kinase 1 regulates SMAD2-dependent TGF- $\beta$ signaling pathway in human glioblastoma. Cancer Res 71: 2392-2402, 2011. 